\title{
Femoral Lymph Node
}

National Cancer Institute

\section{Source}

National Cancer Institute. Femoral Lymph Node. NCI Thesaurus. Code C98183.

A lymph node located in the upper inner portion of the thigh. 